\title{
Nucleophilic Substitution Reactions of Thiophenyl Cyclobutanecarboxylates with Benzylamines in Acetonitrile
}

\author{
Kook Sun Jeong and Hyuck Keun $\mathrm{Oh}^{*}$ \\ Department of Chemistry and Research Institute of Physics and Chemistry, Chonbuk National University, \\ Chonin561-756, Korea. "E-mail: ohkeun@chonbukackr \\ Received Angust 1, 2007
}

Key Words : Nucleophilic substitution, $\Lambda$ cyl transfer reaction, Cross-interaction constant, Kinetic isotope effects, Stepwise mechanism

The aminolyses of acyl compounds have been studied extensively. Brönsted plots were used in these reactions as mechanistic criteria. ${ }^{1.2}$ In many of these nucleophilic reactions curved Brönsted type plots have been found, which have been attributed to a change in the rate-deteming step from breakdown $\left(\beta_{\text {uc }}=0.8-1.0\right)$ to formation $\left(\beta_{\text {nuc }} \equiv 0.1-0.3\right)$ of a tetrahedral intermediate, $\mathrm{T}^{ \pm}$, in the reaction path as a basicity of the amine nucleophile increases. ${ }^{1-6}$ The aminolysis of thiophenyl benzoates with benzylamines, however, exhibited an unusually large $\beta_{\mathrm{X}}\left(\beta_{\text {nuc }}=1.86\right)$ in acetonitrile, which was considered to proceed through a rate-limiting breakdown of a tetrahedral zwitterionic intermediate, $\mathrm{T}^{ \pm}$. Benzylamines are primary amines with relatively high basicities ( $\mathrm{p} K_{\mathrm{a}} \geq 9.0$ ) due to localized cationic charge on the benzylammonium ion and their nucleofugality from $\mathrm{T}^{ \pm}$may be much different from that of the secondary and tertiary amines, especially from a sulfur zwitterionic tetrahedral intermediate since it is known that $\mathrm{ArS}^{-}$is a poorer leaving group from $\mathrm{T}^{ \pm}$than an isobasic $\mathrm{ArO}^{-}$group. ${ }^{7}$ In this paper, we extend our work to the aminolysis of thiophenyl cyclobutanecarboxylates (TCC) with benzylamines (BA) in acetonitrile (eqn. 1).

$$
\begin{aligned}
\stackrel{\mathrm{O}}{\mathrm{C}}-\mathrm{SC}_{6} \mathrm{H}_{4} \mathrm{Z}+2 \mathrm{XC}_{6} \mathrm{H}_{4} \mathrm{CH}_{2} \mathrm{NH}_{2} \stackrel{\mathrm{MeCN}}{350^{\circ} \mathrm{C}} \\
\stackrel{O}{\mathrm{I}}-\mathrm{NHCH}_{2} \mathrm{C}_{6} \mathrm{H}_{4} \mathrm{X}+\mathrm{XC}_{6} \mathrm{H}_{4} \mathrm{CH}_{2} \stackrel{+}{\mathrm{NH}}_{3}+\mathrm{ZC}_{6} \mathrm{H}_{4} \mathrm{~S}^{-} \\
\mathrm{X}=p-\mathrm{OMe}, p-\mathrm{Me}, \mathrm{H}, p-\mathrm{Cl}, m-\mathrm{Cl} \\
\mathrm{Y}=p-\mathrm{Me}, m-\mathrm{Me}, \mathrm{H}, p-\mathrm{Cl}
\end{aligned}
$$

The purpose of the present work is to further expore the effect of the acyl group on the aminolysis mechanism by investigating the structure-reactivity behavior of thiophenyl cyclobutanecarboxylates in acetonitrile. We are interested in the effects of the small ring acyl group on the mechanism, especially on the sign and magnitude of the cross-interaction constant, ${ }^{8} \rho_{x z}$ in eqns. (2a) and (2b), where $X$ and $Z$ are the substituents in the nucleophile, benzylamine,

$$
\begin{aligned}
& \log \left(k_{\mathrm{XZ}} / k_{\mathrm{I} I \mathrm{I}}\right)=\rho_{\mathrm{X}} \sigma_{\mathrm{X}}+\rho_{\mathrm{Z}} \sigma_{\mathrm{Z}}+\rho_{\mathrm{XZ}} \sigma_{\mathrm{X}} \sigma_{\mathrm{Z}} \\
& \rho_{\mathrm{XZ}}=c_{\rho_{\mathrm{Z}}} / \partial \sigma_{\mathrm{X}}=\hat{\gamma}_{\mathrm{X}} / \partial \sigma_{\mathrm{Z}}
\end{aligned}
$$

and leaving group, aryl sulfoxide, respectively. Futhermore, the variation in the kinetic isotope effects, $k_{\mathrm{H}} / k_{\mathrm{D}}$, involving deuterated benzylamines $\left(\mathrm{XC}_{6} \mathrm{H}_{4} \mathrm{CH}_{2} \mathrm{CD}_{2}\right)$ with substituents $\mathrm{X}$ and $\mathrm{Z}$, and the activation parameters, $\Delta / H^{*}$ and $\Delta S^{+}$, are also determined since they can provide valuable information regarding the transition state (TS) structure.

\section{Results and Discussion}

The reactions of benzylamine (BA) with thiophenyl cyclobutanecarboxylates (TCC) under the reaction conditions obey the rate law given by eqns. (3) and (4); $k_{0}$ and $k_{\mathrm{N}}$ are the rate constants for solvolysis in $\mathrm{MeCN}$ and aminolysis of the substrate, respectively. Plots of $k_{o b s}$ against

$$
\begin{aligned}
& \text { Rate }=k_{0 \mathrm{bs}} \cdot[\mathrm{TCC}] \\
& k_{\mathrm{obs}}=k_{0}+k_{\mathrm{N}} \cdot[\mathrm{BA}]
\end{aligned}
$$

benzylamine concentration, [BA], were linear, according to eqn. (4), with the negligible intercept $\left(k_{0} \cong 0.0\right)$, and the slope $k \cdot\left(\mathrm{M}^{-1} \mathrm{~s}^{-1}\right)$ as summarized in Table 1 . No third-order or high-order terms were detected, and no complications were found in the determination of $k_{0}$ ss nor in the linear plot of eqn. (4). This suggests that there is no base-catalysis or noticeable side reactions and the overall reaction follows the route given by eqn. (1). The Hammett coefficients, $\rho \mathrm{x}$ and $\rho_{Z}$, and the Brönsted coefficients, $\beta_{\mathrm{X}}\left(\beta_{\text {huc }}\right)$ and $\beta_{\mathrm{Z}}\left(\beta_{\mathrm{s}}\right)$, are also collected in Table 1 together with the cross-interaction constant $\rho_{\mathrm{xz}}$.

Rates for the aminolysis of thiophenyl (-SAr) cyclobutanecarboxylates are faster than those corresponding values for the aminolysis of phenolate (-OAr) analogues. ${ }^{9}$ Note that the former has a lower rate despite its electron acceptor substituent with a higher reaction temperature (by 20 degrees). Since the nucleophile is the same, benzylamine in both cases, the faster rates of thiophenolates indicate the importance of bond cleavage in the TS, since the thiophenolates used in the present work are weakly basic relative to the phenolates used in the studies and hence are better leaving groups.

The magnitude of $\beta_{\mathrm{X}}$ in Table $1\left(\beta_{\mathrm{X}}=1.48-1.99\right)$ is again much larger than those for the conresponding reactions with anilines and other secondary and tertiary amines $\left(\beta_{\mathrm{X}}=0.6\right.$ $1.0)$ but similar to those with benzylamines $\left(\beta_{\mathrm{x}}=1.4-2.5\right)$. 
Table 1. The Second Order Rate Constants, $k_{\mathrm{N}} \times 10^{3} \mathrm{den}^{3} \mathrm{~mol}^{-1} \mathrm{~s}^{-1}$ for the Reactions of Z-Thiophenyl Cyclobutanccarboxylates with XBenzylamines in Acetonitrile at $35.0^{\circ} \mathrm{C}$

\begin{tabular}{|c|c|c|c|c|c|c|}
\hline \multirow{2}{*}{$\mathrm{X}$} & \multicolumn{4}{|c|}{$Z$} & \multirow{2}{*}{$\rho_{Z^{u}}$} & \multirow{2}{*}{$\beta^{\prime}$} \\
\hline & $p$-Me & $n-\mathrm{Me}$ & $\mathrm{H}$ & $p-\mathrm{Cl}$ & & \\
\hline \multirow[t]{3}{*}{$p-O \mathrm{Me}$} & 7.58 & 15.4 & 24.7 & 115 & $2.97 \pm 0.02$ & $-1.25+0.13$ \\
\hline & $5.46^{\circ}$ & & & 79.4 & & \\
\hline & $3.88^{\prime \prime}$ & & & 55.6 & & \\
\hline$p-\mathrm{Me}$ & 4.89 & 9.58 & 13.2 & 77.0 & $3.02 \pm 0.16$ & $-1.30 \pm 0.02$ \\
\hline $\mathrm{H}$ & 2.50 & 5.78 & 7.57 & 44.7 & $3.12+0.17$ & $-1.35+0.06$ \\
\hline \multirow[t]{3}{*}{$p-\mathrm{Cl}$} & 0.760 & 1.78 & 3.17 & 19.9 & $3.57+0.03$ & $-1.51+0.15$ \\
\hline & 0.539 & & & 14.1 & & \\
\hline & 0.394 & & & 9.73 & & \\
\hline$m$-Cl & 0.381 & 0.921 & 1.55 & 12.0 & $3.77 \pm 0.07$ & $-1.61 \pm 0.11$ \\
\hline$p^{4}$ & $-2.04 \pm 0.06$ & $-1.90+0.09$ & $-1.79+0.09$ & $-1.52+0.02$ & \multirow{2}{*}{\multicolumn{2}{|c|}{$\rho \times z^{e}=1.31 \pm 0.23$}} \\
\hline$\beta Q^{\prime}$ & $1.99 \pm 0.08$ & $1.85 \pm 0.10$ & $1.75 \pm 0.07$ & $1.48 \pm 0.03$ & & \\
\hline
\end{tabular}

${ }^{\circ}$ The $\sigma$ values were laken from Hansch, C.; Leo. A.; Taft, R. W. Chem. Rev: 1991, 91 , 166. Correlation coeflicients were better than 0.997 in all cases. 'The $\mathrm{pKa}$ values were taken from ed., Bukingham, J. Dictiontury of Orgamic Chemistry, Chapman and Hall, New York, 1982, 5 th, ed. $Z=m$-Me was excluded from the Bronsted plot for $b z$ due to an unreliable $\mathrm{pK}$ a values. Correlation coefficients were better than 0.995 in all cases. ${ }^{\circ}$ At $25^{\circ} \mathrm{C}$. ${ }^{\circ}$ At 15 " $\mathrm{C}$. "Correlation coefficients was 0.999. 'The pKa values were taken from Fischer, A.; Glloway, W. J.; Vaughan, J. J. Chem. Soc., 1964, 3588. Correlation coefficients were better than 0.996 in all cases. $\mathrm{pK} a \mathrm{a}=9.64$ was used for $\mathrm{X}=p-\mathrm{CH}_{3} \mathrm{O}$. (relerence On, H. K.; Lee, J. Y.; Lee, I. Bull Korean Chem. Soc., $1998,19,1198$.

All of these latter values are for the thiol ester aminolysis with benzylamines in acetonitrile which are predicted to proceeded by rate-limiting breakdown of a zwitterionic tetrahedral intermediate, $\mathrm{T}^{ \pm}$. On this account, i.e. large $\beta_{\mathrm{x}}$ values obtained, the aminolysis of thiophenyl cyclobutanecarboxylate with benzylamines in acetonitrile is most likely to occur by the rate-limiting expulsion of thiophenolate ion, $\mathrm{ArS}^{-}$, from $\mathrm{T}^{ \pm}$, eqn. (4), where the proton is consumed by the excess benzylamine present in the solution in a subsequent rapid step to form benzylammonium ion. The rate constant, $k_{\mathrm{N}}$ in eqn. (3), is therefore a complex quantity represented by eqn. (5). The magnitude of $\beta_{\mathrm{Z}}\left(\beta_{\mathrm{g}}\right)$ values

$$
k_{N}=\frac{k_{\mathrm{u}}}{k_{-\mathrm{d}}}+k_{\mathrm{b}}=\kappa \cdot k_{\mathrm{i}}
$$

$\left(\beta_{Z}=-1.3 \sim-1.6\right)$ is also comparable to or greater than that for the similar reaction with rate-limiting expulsion of $\mathrm{ArS}^{-}$ in acetonitrile $\left(\beta_{Z}=-1.2 \sim-1.5\right)$.

The proposed mechanism is also supported by a large positive cross-interaction constant $\left(\rho_{\mathrm{X} z}=1.31\right)$ and adherence to the reactivity-selectivity principle (RSP), which are considered to constitute necessary conditions for the rate-limiting breakdown of $\mathrm{T}^{ \pm}{ }^{10.11}$

The kinetic isotope effects $\left(k_{\mathrm{H}} / k_{\mathrm{D}}\right)$ in Table 2 involving deuterated benzylamine $\left(\mathrm{XC}_{6} \mathrm{H}_{4} \mathrm{CH}_{2} \mathrm{ND}_{2}\right)$ nucleophiles in acetonitrile are greater than unity $\left(k_{\mathrm{H}} / k_{\mathrm{D}}=1.3-1.4\right)$, indicating that the $\mathrm{N}-\mathrm{H}$ proton transfer takes place in the rate determining step ${ }^{12}$ so that a four-center type TS is involved. ${ }^{12}$ In this type of TS, hydrogen bonding of an amine hydrogen atom to the departing thiophenoxide facilitates the rate-limiting bond cleavage step, forming a rather constrained four membered ring.

The low activation enthalpies, $\Delta H^{+}$, and highly negative activation entropies, $\Delta S^{+}$(Table 3 ) are also in line with the proposed TS. Especially, the $\Delta H^{+}$values are somewhat lower and the $\Delta S^{+}$values are higher negative values than
Table 2. The Secondary Kinetic Isotope Effects for the Reactions of Z-Thiophenyl Cyclobutanecarboxylates with Deuterated XBenzylarnines in Acetonitrile at $35.0^{\circ} \mathrm{C}$

\begin{tabular}{ccccc}
\hline $\mathrm{X}$ & 7 & $\begin{array}{c}k_{\mathrm{II}} \times 10^{2} \\
\left(\mathrm{M}^{-1} 5^{-1}\right)\end{array}$ & $\begin{array}{c}k_{\mathrm{L}} \times 10^{2} \\
\left(\mathrm{M}^{-1} s^{-1}\right)\end{array}$ & $k_{\mathrm{T}} / k_{\mathrm{D}}$ \\
\hline$p-\mathrm{OMe}$ & $p-\mathrm{Me}$ & $7.58( \pm 0.09)$ & $5.57( \pm 0.05)$ & $1.36 \pm 0.02^{*}$ \\
$p-\mathrm{OMe}$ & $m-\mathrm{Me}$ & $15.4( \pm 0.35)$ & $11.9( \pm 0.15)$ & $1.30 \pm 0.03$ \\
$p-\mathrm{Me}$ & $\mathrm{H}$ & $24.7( \pm 0.30)$ & $19.6( \pm 0.25)$ & $1.26 \pm 0.02$ \\
$p-\mathrm{OMe}$ & $p-\mathrm{Cl}$ & $115( \pm 2.5)$ & $95.0( \pm 1.5)$ & $1.21 \pm 0.03$ \\
$p-\mathrm{Cl}$ & $p-\mathrm{Me}$ & $0.76( \pm 0.01)$ & $0.535( \pm 0.005)$ & $1.42 \pm 0.02$ \\
$p-\mathrm{Cl}$ & $m-\mathrm{Me}$ & $1.78( \pm 0.02)$ & $1.29( \pm 0.02)$ & $1.37 \pm 0.03$ \\
$p-\mathrm{Cl}$ & $\mathrm{H}$ & $3.17( \pm 0.03)$ & $2.42( \pm 0.02)$ & $1.31 \pm 0.02$ \\
$p-\mathrm{Cl}$ & $p-\mathrm{Cl}$ & $19.9( \pm 0.25)$ & $15.9( \pm 0.15)$ & $1.25 \pm 0.02$ \\
\hline
\end{tabular}

"Standard deviations.

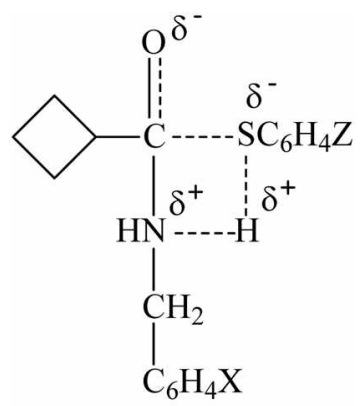

Proposed TS

other aminolysis systems. ${ }^{10}$ The expulsion of $\mathrm{RS}^{-}$anion in the rate determining step (an endoergic process) is assisted by the hydrogen-bonding with an amino hydrogen of the benzylammonium ion within the intermediate, $\mathrm{T}^{ \pm}$. This will lower the $\Delta H^{+}$value, but the TS becomes structured and rigid (low entropy process) which should lead to a large negative $\Delta S^{+}$value.

In summary the aminolysis of thiophenyl cyclobutanecarboxylates with benzylamines in acetonitrile proceeds by 
Table 3. Activation Parameters for the Reactions of Z-Thiophenyl Cyclobutanecarboxylates with X-Benzylamines in Acetonitrile $\Delta$

\begin{tabular}{cccc}
\hline $\mathrm{X}$ & $\mathrm{Z}$ & $\Delta I F^{\mp} / \mathrm{kcal}^{\mathrm{mol}}{ }^{-1}$ & $-\Delta S^{\neq} / \mathrm{cal} \mathrm{mol}^{-1} \mathrm{~K}^{-1}$ \\
\hline$p$-OMe & $p-\mathrm{Me}$ & 5.3 & 51 \\
$p$-OMe & $p-\mathrm{Cl}$ & 5.8 & 44 \\
$p$-Cl & $p-\mathrm{Me}$ & 5.2 & 56 \\
$p$-Cl & $p$-Cl & 5.7 & 48 \\
\hline
\end{tabular}

"Calculated by the Eyring equation. The maximum errors calculated (by the method of Wiberg, K. B. Physical Organic Chemistry, Wiley, New York, 1964, p 378j are $\pm 0.5 \mathrm{kcal} \mathrm{mol}^{-1}$ and \pm 2 e.u. for $\Delta H^{\prime}$ and $\Delta S^{z}$, tespectively.

rate-limiting breakdown of a tetrahedral intermediate, $T^{ \pm}$. The unusually large $\beta_{\mathrm{s}}\left(\beta_{\text {nuc }}\right)$ values can be accounted for by a strong localized cationic charge on the nitrogen atom of benzylamines in $\mathrm{T}^{ \pm}$, which is lost in the benzylamine expulsion from $\mathrm{T}^{ \pm}\left(k_{-a}\right)$. The breakdown rate ratio of $k_{-a} / k_{\mathrm{b}}$ is large due to large $k_{-\mathrm{a}}$ and relatively small $k_{\mathrm{b}}$. The proposed mechanism is also supported by a large positive crossinteraction constant, $\rho_{x z}(=1.31)$, adherence to the RSP, and low activation parameters. The greater than unity $k_{\mathrm{H}} / k_{\mathrm{D}}$ values involving deuterated benzylamines suggests a fourcenter type hydrogen-bonded TS.

\section{Experimental Section}

Materials. Merck GR acetonitrile was used after three distillations. The benzylamine nucleophiles, Aldrich GR, were used without further purification. Thiophenols and cyclobutanecarbonyl chloride were Tokyo Kasei GR grade. Preparation of deuterated benzylamine; benzylamine was dissolved in excess $\mathrm{D}_{2} \mathrm{O}$ under nitrogen atmosphere and left over 5 hours. The deuterated benzylamine was extracted with dry ether and dried again over $\mathrm{MgSO}_{4}$ and then the solvent was removed. This procedure was repeated three times. The anlysis ( NMR) of dried deuterated benzylamine has more than $99 \%$ deuterium content and thus the $k_{\mathrm{H}} / k_{\mathrm{D}}$ values were not corrected for the deuterium content.

Preparartions of thiophenyl cyclobutanecarboxylates. Thiophenol derivatives and cyclobutanecarbonyl chloride were dissolved in anhydrous ether and added pyridine carefully keeping temperature to $0-5^{\circ} \mathrm{C}$. Ice was then added to the reaction mixture and ether layer was separated, dried on $\mathrm{MgSO}_{4}$ and distilled under reduced pressure to remove solvent. IR (Nicolet 5BX FT-IR) and ${ }^{1} \mathrm{H}$ and ${ }^{1 / 3} \mathrm{C}$ NMR (JEOL $400 \mathrm{MHz}$ ) data are as follows:

p-Thiotolyl cyclobutanecarboxylate. Liquid, IR (KBr), $3001\left(\mathrm{C}-\mathrm{H}\right.$, aromatic), $2932\left(\mathrm{C}-\mathrm{H}, \mathrm{CH}_{3}\right), 1709(\mathrm{C}=\mathrm{O}), 1609$ $(\mathrm{C}=\mathrm{C}$, aromatic $) ;{ }^{1} \mathrm{H}$ NMR $\left(400 \mathrm{MHz}, \mathrm{CDCl}_{3}\right), 1.94-2.29$ $\left(6 \mathrm{H}, \mathrm{m}, \mathrm{CH}_{2}\right), 2.39\left(3 \mathrm{H}, \mathrm{s}, \mathrm{CH}_{3}\right), 2.40-2.46(\mathrm{H}, \mathrm{m}, \mathrm{CH}), 7.24$ $(2 \mathrm{H}, \mathrm{d}, J=8.30 \mathrm{MHz}$, meta $\mathrm{H}), 7.34(2 \mathrm{H}, \mathrm{d}, J=8.30 \mathrm{MHz}$, ortho $\mathrm{H}) ;{ }^{13} \mathrm{C}$ NMR $\left(100.4 \mathrm{MHz}, \mathrm{CDCl}_{3}\right), 199.1(\mathrm{C}=\mathrm{O})$, $146.3,138.9,134.1,129.6,124.1,25.9,21.2,17.9$; Mass, $\mathrm{m} / \mathrm{z} 206\left(\mathrm{M}^{+}\right)$. Anal. Calcd. for $\mathrm{C}_{12} \mathrm{H}_{1+} \mathrm{OS}: \mathrm{C}, 69.9 ; \mathrm{H}, 6.81$. Found: $\mathrm{C}, 70.1 ; \mathrm{H}, 6.83$.

$\boldsymbol{m}$-Thiophenyl cyclobutanecarboxylate. Liquid, $\mathrm{R}(\mathrm{KBr})$, 3013 (C-H, aromatic), $2932\left(\mathrm{C}-\mathrm{H}, \mathrm{CH}_{3}\right), 1705(\mathrm{C}=\mathrm{O}), 1584$
$\left(\mathrm{C}=\mathrm{C}\right.$, aromatic); 'H NMR $\left(400 \mathrm{MHz}, \mathrm{CDCl}_{3}\right), 1.92-2.29$ $\left(6 \mathrm{H}, \mathrm{m}, \mathrm{CH}_{2}\right), 2.37\left(3 \mathrm{H}, \mathrm{s}, \mathrm{CH}_{3}\right), 2.33-2.45(\mathrm{H}, \mathrm{m}, \mathrm{CH}), 7.21-$ $7.23\left(4 \mathrm{H}, \mathrm{m}\right.$, aromatic ring); ${ }^{13} \mathrm{C} \mathrm{NMR}\left(100.4 \mathrm{MHz}, \mathrm{CDCl}_{3}\right)$, $199.3(\mathrm{C}=\mathrm{O}), 138.9,135.2,129.9,128.8,127.3,38.8,26.1$. 24.9, 21.3, 18.1; Mass, $\mathrm{m} / \mathrm{z} 206\left(\mathrm{M}^{+}\right)$. Anal. Caled. for $\mathrm{C}_{12} \mathrm{H}_{14} \mathrm{OS}$ : C, $69.9 ; \mathrm{H}, 6.81$. Found: $\mathrm{C}, 70.0 ; \mathrm{H}, 6.83$.

Thiophenyl cyclobutanecarboxylate. Liquid, $\mathbb{R}(\mathrm{KBr})$, 3010 (C-H, aromatic), $1701(\mathrm{C}=\mathrm{O}), 1473(\mathrm{C}=\mathrm{C}$, aromatic); 'H NMR (400 MHz, $\left.\mathrm{CDCl}_{3}\right), 1.88-2.23\left(6 \mathrm{H}, \mathrm{m}, \mathrm{CH}_{2}\right), 2.35-$ $2.45(\mathrm{H}, \mathrm{m}, \mathrm{CH}), 7.38(2 \mathrm{H}, \mathrm{d}, J=7.81 \mathrm{MHz}$, meta $\mathrm{H}), 7.42$ $(2 \mathrm{H}, \mathrm{d}, J=7.81 \mathrm{MHz}$, ortho $\mathrm{H}) ;{ }^{13} \mathrm{C}$ NMR $(100.4 \mathrm{MHz}$, $\left.\mathrm{CDCl}_{3}\right), 198.9(\mathrm{C}=\mathrm{O}), 134.3,130.0,128.9,127.7,46.5,26.1$, 18.0.; Mass, m/z $192\left(\mathrm{M}^{+}\right)$. Anal. Caled. for $\mathrm{C}_{11} \mathrm{H}_{12} \mathrm{OS}: \mathrm{C}$, 68.7; H, 6.31. Found: C, 68.9; H, 6.33.

p-Chlorothiophenyl cyclobutanecarboxylate. Liquid, IR $(\mathrm{KBr}), 3988(\mathrm{C}-\mathrm{H}$, aromatic), $1707(\mathrm{C}=\mathrm{O}), 1498(\mathrm{C}=\mathrm{C}$, aromatic); 'H NMR (400 MHz, $\left.\mathrm{CDCl}_{3}\right), 1.80-2.20(6 \mathrm{H}, \mathrm{m}$, $\left.\mathrm{CH}_{2}\right), 2.25-2.34(\mathrm{H}, \mathrm{m}, \mathrm{CH}), 7.22(2 \mathrm{H}, \mathrm{d}, J=8.78 \mathrm{MHz}$, meta $\mathrm{H}), 7.28(2 \mathrm{H}, \mathrm{d}, J=8.78 \mathrm{MHz}$, ortho $\mathrm{H})$; ${ }^{13} \mathrm{C} \mathrm{NMR}$ $\left(100.4 \mathrm{MHz}, \mathrm{CDCl}_{3}\right), 198.3(\mathrm{C}=\mathrm{O}), 135.5,129.1,126.2$, 46.6, 26.1, 25.3, 22.7; Mass, $\mathrm{m} / \mathrm{z} 226\left(\mathrm{M}^{+}\right)$. Anal. Calcd. for $\mathrm{C}_{11} \mathrm{H}_{11} \mathrm{ClOS}: \mathrm{C}, 58.3 ; \mathrm{H}, 4.91$. Found: $\mathrm{C}, 58.5 ; \mathrm{H}, 4.89$.

Kinetic measurement. Rates were measured conductometrically at $35.0 \pm 0.05^{\circ} \mathrm{C}$. The conductivity bridge used in this work was a self-made computer automatic $\mathrm{A} / \mathrm{D}$ converter conductivity bridge. Pseudo-first-order rate constants, $k_{\text {obss }}$ were determined by the Guggenheim method ${ }^{13}$ with large excess of benzylamine. Second-order rate constants, $k_{i}$, were obtained from the slope of a plot of $k_{\text {obs }} v s$. benzylamine with more than five concentrations of more than three runs and were reproducible to within $\pm 3 \%$.

Product analysis. Substrate $(0.05$ mole) and benzylamine $\left(0.5\right.$ mole) were added to acetonitrile and reacted $35.0^{\circ} \mathrm{C}$ under the same condition as the kinetic measurements. After more than 15 half lives, solvent was removed under reduced pressure and product was separated by column chromatography (silica gel, $10 \%$ ethylacetate- $n$-hexane). Analysis of the product gave the following results.

Cyclobutyl-C(=O)NHCH $\mathbf{C}_{6} \mathbf{H}_{4}-p-\mathbf{O C H}_{3}$. m.p. 192-194 ${ }^{\circ} \mathrm{C}, \mathrm{IR}(\mathrm{KBr}), 3313$ (N-H), $3010(\mathrm{C}-\mathrm{H}$, benzyl), 2965 (C-H, $\left.\mathrm{CH}_{2}\right), 2941\left(\mathrm{C}-\mathrm{H}, \mathrm{CH}_{3}\right), 1700(\mathrm{C}=\mathrm{O}), 1532(\mathrm{C}=\mathrm{C}$, aromatic), 1521 (N-H), 1262, 1035 (C-O); 'H NMR (400 MHz, CDCl $)$, 1.20-1.51 (6H, m, CH$), 1.55-1.66(1 \mathrm{H}, \mathrm{m}, \mathrm{CH}), 3.19(3 \mathrm{H}, \mathrm{s}$, $\left.\mathrm{CH}_{3}\right), 3.62\left(2 \mathrm{H}, \mathrm{d}, \mathrm{CH}_{2}\right), 6.32(2 \mathrm{H}, \mathrm{d}, J=8.78 \mathrm{MHz}$, meta $\mathrm{H})$, $6.55(2 \mathrm{H}, \mathrm{d}, J=8.30 \mathrm{MHz}$, ortho $\mathrm{H}) ;{ }^{13} \mathrm{C} \mathrm{NMR}(100.4 \mathrm{MHz}$, $\left.\mathrm{CDCl}_{3}\right), 173.7(\mathrm{C}=\mathrm{O}), 158.2,131.8,128.5,113.9,113.7,55.3$, 41.6, 24.9, 18.0.; Mass, $\mathrm{m} / \mathrm{z} 219\left(\mathrm{M}^{+}\right)$. Anal. Calcd. for $\mathrm{C}_{13} \mathrm{H}_{17} \mathrm{NO}_{2}: \mathrm{C}, 71.2 ; \mathrm{H}, 7.81$. Found: $\mathrm{C}, 71.0 ; \mathrm{H}, 7.83$.

Acknowledgements. This paper was supported by research fund of Chonbuk National University.

\section{References}

I. (a) Jencks, W. P. Chem, Rev, 1985, 85,51 l, (b) Oh, H. K.; Shin, C. H.; Lee, I. J. Chem. Soc, Perkin Trans. 2 1995, 1169 . (c) Oh, H. K.; Shin, C. H.; Lee, I. Bull. Korean Chem. Soc, 1995, 16, 657. (d) Oh, H. K.; Yang, J. H.; Lee, I. Int. J. Chem. Kinet, 2000, 32, 485 . 
(e) Oh, H. K.; Kim, S. K.; Cho, I. H.; Lee, I. J. Chent. Soc, Perkin Trans. 2 2000. 2306. (f) Oh, H. K.; Kim, S. K.; Lee, H. W.; Lee, I. New J. Chent 2001, 25, 313 .

2. (a) Williams, A. Adv. Phys. Org. Chem. 1992, 27, I. (b) March, J. Advanced Organic Chemistry, 4h ed.; Wiley: New York, 1992. (c) Cullum, N. R.; Renfrew, A. H.; Rettura, J. A.; Taylor, J. A.; Whitmore, J. M. J.; Williams, A. J. Am. Chem. Soc. 1995, 1/7, 9200.

3. Gresser, M.; Jencks, W. P. J. An. Chem. Soc. 1977, 99, 6963, 6970.

4. Castro, E. A.; Ureta, C. J. Org. Chem, 1989, 54, 2153.

5. Castro, E. A.; Ureta, C. J. Org. Chem, 1990, 55, 1676.

6. Cabrera, M.; Castro, E. A.; Salas, M.; Santos, J. G; Sepulveda, P. J. Org. Chem. 1991, 56, 5324 .

7. (a) Hupe, D. J.; Jencks, W. P. J. An. Chem. Soc. 1977, 99, 451. (b)
Jensen, J. L.; Jencks, W. P. J. Am. Chent. Soc. 1979, 101, 1476. (c) Dauglass, K. T. Acc. Chem. Res. 1989, 54, 2153.

8. (a) Lee, I. Chent. Soc. Rev: 1994, 24, 223. (b) Iaacs, N. S. Phssical Organic Chemistry; 2nd ed.; Longman Harlow: 1995; p 186.

9. Lee, H. W; Yun, Y. S.; Lee, B. S.; Koh, H. J.; Lee, I. J. Chem. Soc. Perkin. Trans. 2 2000, 2302.

10. (a) Oh, H. K.; Woo, S. Y.; Oh. C. H.; Park, Y. S.; Lee. I. J. Org. Chem. 1997, 62, 5780. (b) Koh, H. J.; Han, K. L.; Lee, I. J. Org. Chen. 1999, 64, 478.

11. Lee, I.; Lee, H. W. Collect, Czech, Chem. Commm, 1999, 64, 1529

12. (a) Lee, I, Adw: Phys, Org, Chem. 1992, 27,57,

13. (a) Guggenheim, E. A. Phil. Mag. 1926, 2, 538. (b) Oh, H. K.; Oh, J. Y. Bull. Korean Chent. Soc. 2006, 27, 143. (c) Oh, H. K.; Ku, M. H.; Lee, H. W. Bull. Korean Chem. Soc. 2005. 26, 935. 